\title{
Belgeo
}

Revue belge de géographie

1-2 | 2012

Inaugural issue

\section{The European City in the Age of Globalisation}

La ville européenne à l'ère de la globalisation

\section{Walter Matznetter and Robert Musil}

\section{OpenEdition}

\section{Journals}

Electronic version

URL: http://journals.openedition.org/belgeo/6100

DOI: 10.4000/belgeo.6100

ISSN: 2294-9135

\section{Publisher:}

National Committee of Geography of Belgium, Société Royale Belge de Géographie

\section{Electronic reference}

Walter Matznetter and Robert Musil, «The European City in the Age of Globalisation », Belgeo [Online] 1-2 | 2012, Online since 15 December 2012, connection on 30 April 2019. URL : http:// journals.openedition.org/belgeo/6100; DOI : 10.4000/belgeo.6100

This text was automatically generated on 30 April 2019.

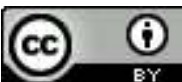

Belgeo est mis à disposition selon les termes de la licence Creative Commons Attribution 4.0 International. 


\section{The European City in the Age of Globalisation}

La ville européenne à l'ère de la globalisation

Walter Matznetter and Robert Musil

\section{Introduction : the gap between Global City and European City debates}

1 Two recent publications are good illustrations of the lack of integration, or even debate, between two strands of research converging upon the same phenomenon: cities in Europe. In the "International Handbook of Globalization and World Cities" (Derudder $e t$ al., eds., 2012), European cities are included in most of its 50 chapters, and some European cities receive a chapter of their own (London, Randstad, Brussels, Berlin, Warsaw). In his re-edition of "Le retour des villes européennes" (2011), Patrick Le Galès confirms and elaborates his original thesis of the specificities of the "European City". The first book is a flagship outcome of Global City research, the second by one of the most dedicated proponents of the idea of a European City. The first focuses on external relations of cities, predominantly at the global level, while the second focuses on multi-level urban governance and internal relations, insofar as these interactions are mainly within the urban region, the nation-state, or at most within the European Union. When reading both books, the remarkable finding is that there is hardly any cross-reference; hardly any European City theorist is quoted in the Globalization Handbook, and hardly any Global City author is noted in Le Galès' new preface. This article will address this lack of overlap.

2 The European City, as a category of urban research, is a challenging term. One hundred years ago, Max Weber gave a historical definition of the city in Europe that focused on the specificities of the medieval city. In his view, partial political autonomy, urban jurisdiction, the formation of guilds, the existence of a marketplace, and a delimitation by city walls had made European cities very specific communities, places that were distinct 
from the rest of society (Weber, 1976, pp.736, 788-794). Over the centuries, with industrialisation and the spread of capitalism and urbanisation, these distinctive features were lost, and so was the applicability of the concept of the European City. With the rise of the nation-state, and the rise of Fordist national economies, cities were studied as part of their national territories. From the 1920s into the 1970s, urban geographies were written about the Italian (Dematteis et al., 1978) or the German City (Schöller, 1967), embedded in their respective national institutions, but there were hardly any attempts to generalise the features of all cities in Europe.

3

Since the 1970s, alongside the horizontal and vertical expansion of the European integration processes and the end of Europe's division in 1989, the question about the European City and its future came to the fore (Lichtenberger, 1970, 1972). Urban researchers broadened their topics, such as suburbanisation (Szirmai ed., 2011) and postsuburbanisation (Phelps et al., 2006), commercial streets and retail (Schröder, 1999), housing (Kleinman et al., 1999) or the socio-spatial impact of international migration (Pennix et al., 2006) to a European scale - inspired and often funded by the European Union.

4 Paradoxically, parallel to the reinforcement of research aiming at a European scale and the European City, so-called "de-territorialisation theories" underline the rise of a city network on a global scale, wherein processes on the local level are determined by the intensity and the form of a city's integration into the global economy (Friedmann, 1986; Sassen, 1991; Castells, 2001). The initial point in this paper is not the (widespread) question of the disappearance of the European City, but the identification of a gap between two perspectives of research : firstly, the perspective of the Global City, which explains urban development from a global perspective; secondly, the perspective of the European City, which is more oriented towards classic topics of urban research. It is the intention of this paper to argue for the necessity of combining both perspectives to capture the European City in the age of globalisation.

\section{European Cities in the network of the global economy}

With an increasingly integrated globalised economy, the rise of multinational enterprises and global production networks, the impact of these processes on urban development has become an emerging field of research. Two influential approaches or theories on the consequences for the European City will be discussed in this section : the "Informational Society" (Manuel Castells) and the "Global City Theory" (Saskia Sassen).

6 Castells' theory focuses on the "rise of the network society", which is characterised by a new spatial category, the "space of flows". As a consequence of the information technology revolution and the globalisation of capitalism, the space of flows dominates over the "space of places" - the latter of which carries the characteristics of the European City (Castells, 2001, p. 480). Increasing social fragmentation and global integration brings the European City - as an entity - into question : "The transformation of European cities is inseparable from a deeper structural transformation that affects urban forms and processes in advanced societies: the coming of the informational city" (Castells 1993, p. 253). Although Castells emphasises that the social consequences of this transformation are different among cities (ibid., p. 248), his arguments aim at a world-wide transformation towards a new type of city - the Informational City. 
7 Both arguments - urban transformation towards social polarisation and global integration - have been carried forward by Saskia Sassen in the Global City Theory (Sassen, 1991). Therein she focuses on cities as places that provide highly specialised and therefore spatially concentrated - knowledge, which is essential for multinational enterprises to manage global production networks and value chains. The global relevance of a city is based on its global centrality and on its function as a marketplace for the knowledge to control the global economy, which is provided by globally-oriented producer service firms (Sassen, 1991, pp. 4f.). This global integration of cities coincides with a new geography on the local level, which can be described as ongoing social and spatial fragmentation. While high value service sectors create new jobs in the city centres and financial districts, traditional sectors of production and consumer-oriented services experience a devalorisation; the structural change of the labour market leads to increasing social disparities and unemployment rates (ibid., pp. 245ff.). This dualism, which is reinforced by the international migration of high and low-skilled workers, brings together elements of the First and the Third World on a local scale - the thesis of social polarisation is a crucial element of the Global City.

What about Global Cities in Europe? This question is insofar relevant, as Sassen emphasises the universality of her analyses : "Thus a new type of city has appeared. It is the global city" (Sassen, 1991, p.4). Focussing on the links and flows of the global economy and its relevant actors - such as multinational enterprises -, the impact of the state and of national welfare systems on social and spatial structures of the city has received little attention. Therewith, the Global City Theory must be added to the "deterritorialisation theories" (e.g. Agnew 1994 ; Castells, 2001), which neglect the role of territorial entities for global processes (Keil and Brenner, 2003). In sum, both theories question the continuity of the European City as an entity in the age of globalisation.

\section{Some empirical facts on European Global Cities}

9 Against the background that Sassen's theory was based on three specific case studies London, New York and Tokyo - the polarisation thesis was questioned with empirical studies. For instance, Hamnett's analysis of the labour market and the development of unemployment showed that the nature and the causes of polarisation and the extent of social disparities differ between American and European cities (Hamnett, 1996, p. 108). Although he confirms the increase of highly skilled and highly paid professionals in the case of London - the same as in Amsterdam and Paris -, this occurred parallel to an increase of low skilled jobs. Eventually, inequality rose, but polarisation did not occur (Hamnett, 2003, p. 102).

10 The "American interpretation", on which the Global City Theory is based, neglects the role of welfare systems and their impact on income inequality as well as the role of the public sector as an employer (Hamnett, 1996, p. 108). Besides economic cycles, Fainstein (2001) also stresses the impact of welfare systems on the labour market and social structure, which produce a heterogeneous pattern of social inequality in Europe. Other authors neglect the connection between specialisation in the service sector and the concentration of immigrants in low-valued service sectors (Häussermann and Roost, 2000 , p. 89) ; for these authors, social polarisation in Europe is more a phenomenon of post-industrial cities than of the centres of global finance. 
11 In the research on European Global Cities, the thesis of a dual city has been largely discarded - the general link between the global economy and social processes on the local urban level seems to be moderate and needs to be further specified. It neglects the fact that cities are embedded in institutional systems : the welfare state, spatial redistribution mechanisms between territorial subunits and strong public sectors that in sum produce national variations of capitalist societies (cf. Hancké ed., 2009). European cities notwithstanding their differences - seem to illustrate well "that there are no direct and simple links between economic globalisation and local outcomes" (Häussermann and Haila, 2004, p. 50).

\section{The European City as a node in the Global City Network}

12 The second theoretical strand of Global City Theory concerns the cities' integration into the global urban system. Therefore, Sassen claims that Global Cities do not exist as individuals, but rather as a network - consequently, a Global City can only be analysed as part of a network. The high requirement for data leads to a gap between the intensive theoretical debates and the empirical findings. This gap has been characterised as the "dirty little secret of global city research" (Short et al., 1996). To overcome this shortcoming, Peter Taylor and the "GaWC Group" (Globalization and World Cities Research Network) developed a relational database, consisting of a network of service firms surveyed in the years 2000 and 2008, of 100 (and later 175) firms located in 315 (and later 525) cities (Derudder et al., 2010). Therewith, a worldwide analysis of cities concerning their "globalcityness" was possible.

13 Based on these data, Taylor and Hoyler (2000) analysed 53 European cities. The outcome of their analysis is a classification of European cities that redraws the historic "citystudded Europe as the central economic spine of the continent running from the Baltic through the low countries and Rhinelands to northern Italy" (ibid., p. 177), which has been defined in Stein Rokkan's model of Europe's political and economic system (Flora 2000, p. 179). As Hohenberg and Lees (1995) highlight, the "peripheral" urban systems in Southern and Eastern Europe differ in respect to their density (ibid., p. 246). In their analysis, Taylor and Hoyler (2000) show that recent processes of globalisation do not occur in an "empty space"; rather, the infrastructure of producer oriented service firms seems to reinforce existing spatial structures. The authors were able to identify a spatial pattern, dividing Europe's cities into a major and minor urban spine and a number of outer, peripheral arenas (ibid., p. 187).

Furthermore, this classification shows that the recent process of globalisation does not lead to an enclosed European urban system. European cities are part of a wider global urban system, wherein some cities differ from their intra-European connectivity - they are "un-European", for two reasons : first, because of local specificities (e.g. Budapest, St. Petersburg) or second, because of their intensive integration into the global financial markets (e.g. London, Paris, Zurich) ; (ibid., p. 187 ; Taylor, 2004). Therefore, the relations of the European City system do not end at Europe's borders - they seem to be rooted in historic spatial patterns, but follow the logic of a globalised and borderless economy. In an additional analysis, Taylor and Derudder (2004) strengthen the argument to extend Europe's urban system beyond the continent's border: the major spine cities are integrated into global urban arenas, while those of the minor spine are more limited to the European arena. In other words, London's integration into an urban system cannot be 
explained without looking towards New York; for the case of Madrid, Latin America has to be considered (ibid., p. 534). In short, the explanatory power of an urban system within a single territorial scale must be rejected on both the scale of the state and the scale of the European continent. From this perspective, not just the "European City" as a generic concept, but also the "European urban system" is seen as a questionable approach.

However, beside methodological critique (for an overview see Gerhard 2004, p. 8), such as the relevance of GaWC firms within the urban economy of Global Cities, another aspect of these empirical findings on the "European urban system" seems questionable. For instance, Taylor et al., (2011) highlight the difference between "German" and "British" or "French" cities in the Global City network by their distribution : with several Global Cities holding a medial connectivity, Germany shows a "horizontal" pattern of integration in the Global City network (cf. Hoyler, 2011). By contrast, French cities seem to show a vertical integration, with Paris as an important, but singular Global City on the national scale (Taylor et al., 2011, p. 127). Global City Theory does not offer a conceptual explanation for these findings. The "country effect" has also been highlighted by Bourdeau-Lepage $(2004 ; 2007$, pp. 142f.) : focussing on the capital cities of CEE countries, she concludes that there is "potential for city globalisation, indirectly through the type and the stability of government, but also directly through regional and urban policies" ( ibid., p. 143).

But the territorial perspective is also relevant on the regional scale for two reasons. First, it sheds light on strategic resources and non-tradeable agglomeration economies produced by territories and local institutions; the city can thus be understood as a cluster that produces diversification and specialisation, density of proximity contacts and low transaction costs (Camagni, 2001, pp. 101f.). Second, there is the question of the spatial organisation of Global City functions ; the global centrality of a Global City has not exclusively been produced within a CBD, but within a wider region (Sassen, 2001, p. 85).

In short, in regards to the socio-spatial order of the Global City, we have to look for structures and processes in the background that enable the global integration of a city, but more often follow the territorial logic of the state and its institutions, rather than the relational logic of the Global City (Le Galès, 2002, p. 155). Proceeding with Saskia Sassen, by analysing the "European City" and the "European City System", we have to avoid the so-called "endogeneity trap" (Sassen, 2006, p. 4). This means that the recent integration of a city into the Global City network should not be explained by recent global processes alone, but also by examining the historical evolution of the surrounding nation-state, its territorial structure and its institutions. So, what are these structures and processes that enable cities to integrate in the Global City network?

\section{Concepts of the European City}

More often than not, concepts of the European City have been developed from a perspective outside of the Old Continent. One hundred years ago, a party of 43 European geographers embarked on a railway journey across the USA, the "Transcontinental Excursion of 1912". Amongst the many publications that followed from that experience, Eugen Oberhummer, then president of the Austrian Geographical Society, reflected upon the differences between "American and European Cities" (1915). 

to the long history of their European counterparts, with all their repercussions in the urban fabric. In US cities, rectangular layouts predominate, whilst irregular patterns are frequent in Europe, particularly in the pre-industrial city cores. In American city centres, the European visitor was struck by the first "sky-scrapers", such as the Woolworth Building in New York, then under construction. Not surprisingly, it was mainly the urban skyline and morphology by which the American city was distinguished from the European one. Apart from a few casual observations on the racial mix of the inhabitants, Oberhummer did not comment on American society and politics. European cities were said to look different from American cities, but geographers did not yet ask whether they function in a different way.

The important aspect of such reasoning is that it was on Europe as a whole. For decades to come, such generalisations will be pushed aside by nation-based generalisations of the city. In the first collection, in German, on culture-specific cityscapes we find a chapter devoted to German and Spanish cities, followed by chapters on North American and Australian cities (Passarge ed., 1930). In a similar vein, Burkhard Hofmeister's textbook on urban geography (1969) included chapters on the Central and Western European City, the Northern and Eastern European City, the Russian-Soviet City, and the Southern European City, alongside the Anglo-American and the Latin American City. As a category of its own, the European City emerges only in his later writings, e.g. Hofmeister (1980). Again based on the experience of time spent in North America, geographer Elisabeth Lichtenberger (1970) defined the particularities of the European City as mainly morphogenetic. The physical traces of one or two millennia of urban development contribute to an urban morphology that is considered unique. Street networks and plot layout often predate industrialisation, skylines are tamed by conservative building codes and preservation orders, and housing is dominated by rented apartments, mixed with offices and workshops on a small scale. In the $20^{\text {th }}$ century, variants of welfare regimes added their imprint on European cities : public utilities, public transport, public and social housing, garden cities and green belts are more frequent here than in other regions of the world. Due to these policies, social segregation is less pronounced in European cities than elsewhere, and the city centre has remained an attractive place for housing, work, shopping and leisure.

21 In urban sociology, Max Weber's writings on the medieval city are often quoted as a summary of the specificities of European cities. The city walls, the city market, its own jurisdiction, the formation of guilds, and the (partial) political autonomy of cities (1976, pp. 736, 788ff.) are said to be characteristic features of the past. For European cities of today, the sociologist Walter Siebel proposes another list of specificities. Firstly, the ageold buildings and architecture impinge upon the lives of contemporary city-dwellers, thereby "making pre-modern history present". Secondly, for centuries, European cities have been at the origin of social emancipation and revolution. Thirdly, the style of urban living allows citizens to move between the public and the private with ample facilities for public life. Fourthly, this is aided by a long tradition of urban planning that has preserved the city centre and moulded the cityscape since the Middle Ages. Lastly, over the long $20^{\text {th }}$ century, social infrastructure and its management have been added to the agenda of urban planning, creating the "Social City".

There are some basic similarities in these concepts of the European City: both geographers and sociologists examine the internal structure of cities, focussing on its 
visual features, which include massive traces of the Keynesian welfare state. They tend to neglect the external linkages amongst European cities, as well as the networks that tie European cities into the global network of cities. Even when these networks are based upon tangible, material flows, of goods or people, they tend to escape the eye of the observer of the European City. When it comes to intangible, digital flows of capital or information, this invisibility is almost perfect and only the physical outcomes are recorded.

Definitions of the European City that focus on the built environment fall into a similar endogeneity trap as that of their colleagues from Global City research (as portrayed in chapter 1). They try to pin down Europeanness by means of internal, intra-urban, and visible phenomena alone. As the proponents of such concepts continue to stress, such features of the European City go back to pre-modern, early industrial, or at best FordistKeynesian times. Such definitions tend to overlook post-Fordist developments in today's cities of Europe.

Since the 1990s, political scientist Patrick Le Galès has developed a definition of the European City that is based on its more recent specificities, despite the strong winds of globalisation. In a new foreword to the $2^{\text {nd }}$ edition (2011) of his bestselling "Le retour des villes européennes" (2002), he confirms and specifies these features : amongst all cities worldwide, European cities are special regarding their sizes, their interaction, their longterm stability, and their protection by the (welfare) state. Apart from London and Paris, there are no mega-cities amongst them, but there is a dense network of middle-sized cities between 200,000 and 2-3 million inhabitants, particularly along the famous "Blue Banana", allowing for intensive communication and exchange, including daily return trips (cf. Rozenblat and Cicille 2004, pp. 26f.). Concerning power relations, cities are seen as benefitting from European integration, which implies both the relaxation of central state control and the instalment of cities and regions as political players in their own right. Urban governance's room for manoeuvring has increased, and many cities of Europe have gained from their engagement in infrastructure and their branding as "European Cities". In part, such images are a myth, but it is a myth that contributes to investments and growth. Shrinking cities or desurbanisation have not become widespread, but re-urbanisation and urban growth are common features of many European cities today. Within European metropolitan regions, political power is still in the central cities, and not in (post-) suburbia, stresses Le Galès. Public infrastructure and public sector employment are considered important elements of the European City.

In his book on "New State Spaces" (2004), transdisciplinary social scientist Neil Brenner gives a comprehensive portrait of all the changes that have accompanied the transformation of the Fordist-Keynesian welfare state into the post-Keynesian competition state. For Brenner, the "rescaling of statehood" is a key feature of these processes, where agendas that used to be addressed by the nation-state are split and transferred to both supra-national and sub-national arenas. In empirical terms, most of his material is on Western European states, regions and cities, and includes a wealth of information on the latter. In contrast to Le Galès, he is less optimistic about the future and sustainability of the European City, whose specificities he sees as falling prey to the forces of global and inter-urban competition.

26 According to Brenner, the dominant urban policy can be circumscribed as "urban locational policy", where non-accountable quango organisations, operating at various scales, tend to aggressively compete for profit maximising investment. Place marketing 
and branding receives top priority, overshadowing all former social redistributive and regional equalisation policies of the welfare state. Not surprisingly, new pan-European patterns of prosperity and marginalisation are emerging, replacing the formerly national urban hierarchies. "Archipelago Europe" is the name proposed by Petrella (2000) for such a network of increasingly interconnected cities and metropolitan regions, immersed in a sea of semi-peripheral and peripheral regions. Following Soja (1985), he remarks that the new European patterns of unequal development are building on and reviving $19^{\text {th }}$ century patterns of industrialisation and urbanisation.

Both Le Galès' optimist and Brenner's more pessimist interpretations (cf. Giersig, 2008, pp.19f. for these qualifications) are in line with empirical findings such as those documented in Vandermotten et al.'s comparative atlas (1999), or in Rozenblat-Cicille's comparative analysis (2003) of European cities. In a number of introductory chapters, the authors of the first publication are keen on elaborating a broad and long-term picture of the European urban system which goes beyond a mere ranking of metropolitan regions. Apart from confirming the major European spine, stretching from London to Milan, two types of urban systems are being put forward : a Rhenish type (made up of many middlesized cities, in close proximity to each other), and a Parisian type (made up of a very large primate city, dominating a vast hinterland with comparatively low densities, and much smaller regional cities within or beyond that hinterland; cf. similar map in Hohenberg and Lees 1995, p. 246). Both types are present across the continent, with the Rhenish type confined to the most urbanised regions of Europe, and the Parisian type frequent in the European peripheries. In such a way, attention is drawn to the spacing of European Global Cities - which is quite distinct from most other world-regions. The relative proximity of cities along (and on both sides of) Brunet's "Blue Banana" allows for daily return trips for business, or weekend trips for leisure (cf. Rozenblat and Cicille, 2004, p. 33). However, none of the European City writers have much to say about the position of European cities within the network of Global Cities.

\section{Towards a research agenda}

\section{Linking external and internal relations}

One of the basic assumptions of Global and World City research is that there is a connection between the global integration of a city and "structural changes occurring in it" - concerning the labour market as well as the "physical form" of the cities (Friedmann, 1986, p. 70). Sassen also follows that assumption (Sassen, 1991, p. 9). This aspect is relevant insofar as the small number of advanced producer service firms, which are the basic indicator for the "connectivity" in the GaWC network, hold just a very small share in the urban economy. Even in New York, London and Tokyo, the globally oriented service and finance sector does not account for more than 15 per cent of all employees (Storper, 1997, p. 225) ; thus, the analysis of the urban economy and its global integration must consider other branches of the economy as well, such as export-oriented industrial production. Storper warns against reducing the question of the global-local interplay in the cities to a "yuppie plus servant classes analysis" (Storper, 1997, p. 232). It is surprising that the popular hypothesis of Friedmann (1986) has been widely accepted in urban research, even though it still needs a more elaborated empirical foundation. 
To broaden the understanding of the connection between global integration and internal urban processes, we suggest focussing - in addition to the service branches - on the two pillars of the internationalisation of an economy : foreign direct investments (FDI) and the export of commodities and services.

- Although there is a severe lack of FDI data on the urban/regional level, this indicator - as the so-called "vehicle of globalisation" (Wu and Radbone, 2005) - says a lot about the internationalisation of a city's economy. Beside the number of incoming and outgoing investments, the relevance of these multinational enterprises can be measured by the number of their employees in the urban labour market, or their asset capital. We suppose that the unevenness of interurban capital flows says more about the position of a city in the central-peripheral system than the subsidiaries of a small number of service firms.

- The regional balance of trade as well as the size and the structure of a city's export sector are a valuable indicator for the level of high-tech production and the competitiveness of an urban economy. Although the differentiation between an export-oriented "basic sector" and a "non-basic sector" is a difficult challenge (Läpple, 2000), the urban economy should not just be analysed by what it produces (following the traditional branch structure), but also how it produces - e.g. knowledge based, organised in clusters, linked into global commodity chains?

\section{Avoiding endogeneity : regimes, pathways, nation-states}

A phenomenon - like globalisation - cannot be understood only by describing and analysing its own characteristics. The explanation must focus on those structures that enable recent processes. This, in a nutshell, is the main assumption of Saskia Sassen's "endogeneity trap" (Sassen, 2006, p. 4), wherein she notes the necessity of looking for structures and their historic origins - e.g. the nation-state - that do not follow the logic of globalisation, but have an impact on the evolution of these processes. In our understanding, European cities and their relevance within the Global City network are a worthwhile field to analyse these factors. Therefore, it makes sense to ask what structures were relevant for the production of Global Cities - their internal structure as well as their external integration. Hence, we suggest focussing on the following fields of research :

- The existence of powerful welfare states is the main reason for the low level of socio-spatial polarisation in the European City. However, the question arises on how various welfare regimes (liberal, social democratic, conservative) differ in their impact on the social structure of the urban societies (cf. Kazepov, 2005, pp. 16f.; Matznetter and Mundt, 2012). Social housing might be a useful starting point for comparison.

- As European cities are very old, the impact of historic pathways on their recent position in the Global City network is self-evident. London's global city status cannot be explained without examining its role as the epicentre of the British colonial empire (Zehner, 2011). The number of cities with historic pathways in Europe is long: Frankfurt's relevance as an international financial centre goes back to 1948, when the Allied administration in Western Germany decided to locate the "Bank deutscher Länder" in this city (Schamp, 2011). Vienna's recent role as a gateway between East and West goes back to the Austro-Hungarian Monarchy (Musil, 2009).

- With its policies, the nation-state supports the transformation of cities or capital cities into Global Cities (Keil and Brenner, 2003). The organisation of administrative units, the investment in public transport and communication infrastructure are cases in point. In a 
less direct way, national economic policy or even the size of the national economy and the economic and military power associated with it are important. The British government's "Big Bang" of 1986, the starting point for the rise of London's finance industry, is a good example for such an effect (cf. Zehner, 2011).

\section{Territorial arrangements}

Undoubtedly, the "space of places" (often "central places") of old has lost importance in the informational age, which is increasingly dominated by the "space of flows". However, location and space have not disappeared altogether, and Global Cities do have coordinates in GIS systems, and they are physically present, some close to each other in so-called Global City Regions, others standing alone as isolated outposts of the global economy.

In Global City research, data on individual cities are often visualised with boxes that are joined together in a domino-like diagram that annihilates distance between them. In some regions of the world, notably in Europe, the boxes are so densely packed that for graphical reasons they cover a disproportionate area of the global "map". In fig.1, we have relocated 132 Global Cities (from Derudder et al., 2010) to their approximate site on a topographical world map. Here, the uneven distances and the discontinuities between Global Cities come to the fore. For information flows, these gaps may be negligible, but they are not negligible when it comes to the internal impacts of "globalcityness". From a global viewpoint, Europe's Global Cities constitute a single continental "Global City Region".

Figure 1. Geographical distribution of 132 Global Cities.

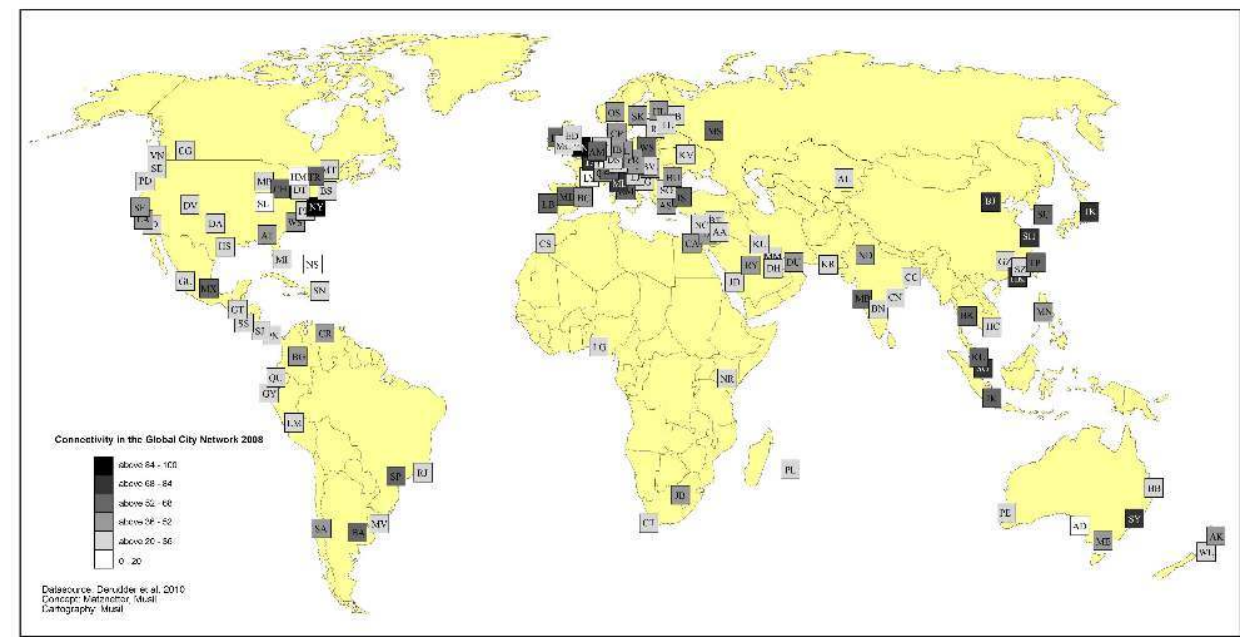

SOURCE : DERUDDER ET AL., 2010.

\section{The European Scale}

For the 47 cities of Europe that qualified for the 2008 round of GaWC research, the boxes cannot be properly displayed on a world map. In fig.2, we zoom in on European Global Cities to give an impression of their concentration or dispersion across the old Continent. Even in this figure, overlap cannot be avoided in the most urbanised areas of NorthWestern Europe. These cities, Amsterdam, Rotterdam, Antwerp, Brussels, are part of the 
"Blue Banana", the major European spine of Global Cities, stretching from Dublin to Milan. Global Cities within these city-dense regions are not only important players worldwide, but they also interact intensively with their close neighbours, developing into the "polycentric metropolises" analysed by Hall and Pain (2006), or "Global City-Regions" (Pain, 2012).

In the city-poor, semi-peripheral to peripheral regions of Europe, the role and impact of the Global Cities in that region are quite different. These are often the capital cities of smaller nation-states, which tend to trade on their gateway role for international business and capital, and thereby monopolise that role at the expense of their hinterland and lower-tier cities.

Figure 2. Geographical distribution of 47 Global Cities in Europe.

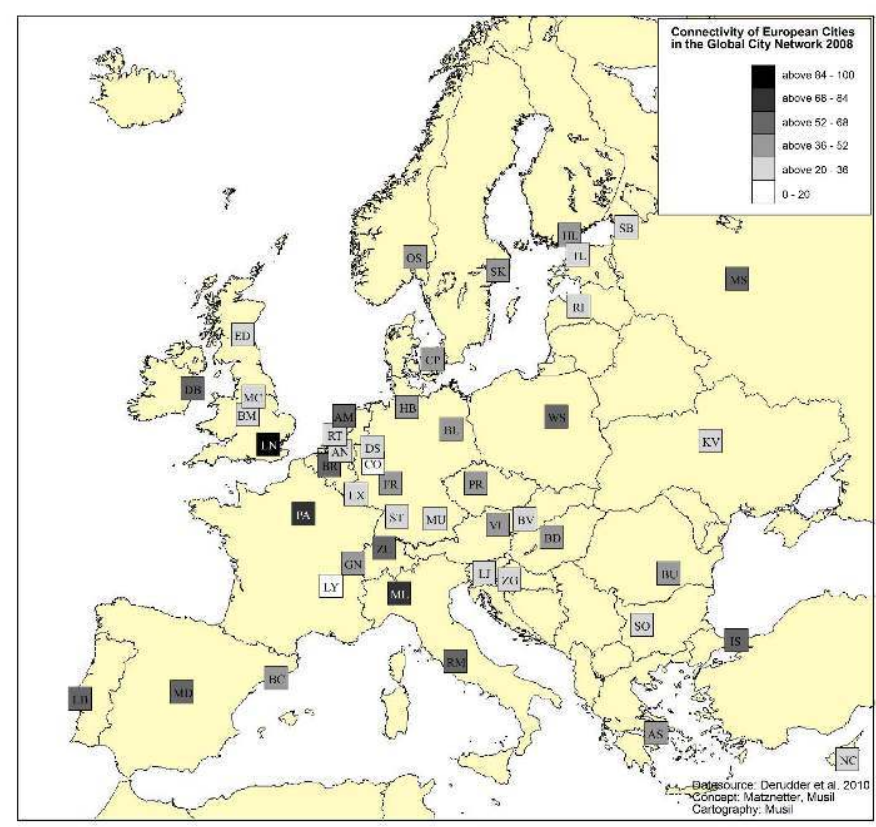

SOURCE : DERUDDER ET AL., 2010).

\section{The National Scale}

A wide range of inter-regional disparities can be found among European states, from ("Parisian") centralism and ("Rhenish") decentralism in the urban system to economic dynamics. These structures on the national scale go back to long-term, often historical developments and territorial arrangements that influence the recent integration of their cities into the global economy.

In contrast to the "de-territorialisation theories", which by-pass the role of the nationstate and understand urban development as interplay between the global and local scale, we suggest taking into account the impact of the nation-state on urban development as well. Keil and Brenner (2003), for instance, give several examples - such as the Randstad and several American cities - where the evolution towards a Global City is the result of a 
deliberate national strategy. Besides the immediate governmental agglomeration policy, the territorial organisation of the state - like the degree of federalism or centralism - and its spatial redistribution mechanism influence the scope of action for cities, in financial aspects as well as in legislative questions.

Although we must be aware of the danger of a "territorial trap" (Agnew, 1994), the national scale and its impact on urban development and on the integration of cities into the global economy must be considered. In this context, the role of different variants of European welfare states (after Esping-Andersen, 1990) or of different "varieties of capitalism" (e.g. Hancké ed., 2009) on Global City formation could be elaborated.

\section{The Regional Scale}

On the regional scale, we can identify two variants of Global City Regions : one that is predominant in the city-packed and polycentric regions of the core European spine, and one that is typical for the many monocentric Global Cities in the city-poor, semiperipheral to peripheral regions of Europe.

For the polycentric mega-city regions of North-Western Europe, Hall and Pain (2006) have laid the foundations with the POLYNET project, covering eight MCRs in great detail. In addition to the worldwide linkages studied by GaWC, short distance linkages and cooperation between neighbouring Global Cities and within Global City Regions are brought to the fore in this seminal study. In the years to come, this work must be carried forward.

In the monocentric Global City Regions outside the European "Pentagon area", Global City formation engages with the classical processes of suburbanisation in functional city regions. In American cities, the rise of "Edge Cities" (Garreau, 1991) proceeded with a decentralisation of a city's global centrality that did not have to follow the centrality of the core city (Sassen, 2001, p. 85). With the debate about "Post-Suburban Europe" and the functional emancipation from the core city (Phelps et al., 2006) we must ask whether the suburban zones of European cities produce their own global centrality, or if they are just the functional, subordinate supplement of the core city.

\section{Final remarks}

41 This article is based upon editorial work for Matznetter and Musil (eds., 2011), in which we tried to bridge the gap between analyses of European cities as Global Cities and analyses of intra-urban economic, demographic, social and political processes. Through collaborating with 24 authors at 15 European universities, we have learned to substantially expand our own specialised, language- and place-specific views on Global Cities. In this article, we would like to share some of these pan-European insights with colleagues worldwide, and we think that the relaunch of Belgeo is a perfect opportunity to ask for comments and critique. 


\section{BIBLIOGRAPHY}

AGNEW J. (1994), “The territorial trap : the geographical assumptions of international relations theory", Review of International Political Economy, 1, 1, pp. 53-80.

BOURDEAU-LEPAGE L. (2004), "Metropolization in Central and Eastern Europe : Unequal Chances", GaWC Research Bulletin, 141, http://www.lboro.ac.uk/gawc/rb/rb141.html ; 30. 4. 2012. BOURDEAU-LEPAGE L. (2007), “Advanced services and city globalization on the Eastern fringe of Europe", Belgeo, 2007, 1, pp. 133-146.

BRENNER N. (2004), New state spaces. Urban governance and the rescaling of statehood, Oxford University Press, Oxford.

CAMAGNI R. (2001), "The economic role and spatial contradictions of global city-regions : the functional, cognitive and evolutionary context", in SCOTT A. A. (Ed., 2001), Global City-Regions. Trends, Theory, Policy, Oxford University Press, Oxford, pp. 96-118.

CASTELLS M. (1989), The Informational City. Information Technology, Economic Restructuring, and the Urban-Regional Process, Basil Blackwell, Oxford.

CASTELLS M. (1993), "European Cities, the Informational Society, and the global Economy", Tijdschrift voor economische en sociale geografie, 84, 4, pp. 247-257.

DEMATTEIS G., GAMBI L., MANCUSO F., MIONI A., SANFILIPPO M., SUSINI G. (1978), Le Città, Touring Club Italiano, Milano.

DERUDDER B., TAYLOR P. J., NI P., DE VOS A., HOYLER M., HANSSENS H., BASSENS D., HUANG J., WITLOX F., SHEN W. and YANG X. (2010), "Pathways of Change : Shifting Connectivities in the World City Network, 2000-2008”, Urban Studies, 47, 9, pp. 1861-1877.

DERUDDER B., HOYLER, M., TAYLOR, P.J. and WITLOX, F. (Eds.) (2012), International Handbook of Globalization and World Cities, Edgar Elgar, Cheltenham.

ESPING-ANDERSEN G. (1990), The three Worlds of Welfare Capitalism, Polity Press, Cambridge.

FAINSTEIN S. S. (2001), "Inequality in Global City-Regions”, in SCOTT A. A. (Ed.) (2001), Global CityRegions. Trends, Theory, Policy, Oxford University Press, Oxford pp. 285-298.

FLORA P. (2000), Stein Rokkan : Staat, Nation und Demokratie in Europa, Suhrkamp, Frankfurt am Main.

FRIEDMANN J. (1986), “The World City Hypothesis“, Development and Change, 17, 1, pp. 69-84.

GARREAU J. (1991), Edge City : Life on the New Frontier, Doubleday, New York.

GERHARD U. (2004), “Global Cities. Anmerkungen zu einem aktuellen Forschungsfeld”, Geographische Rundschau, 56, 4, pp. 4-11.

GIERSIG N. (2008), Multilevel Urban Governance and the European City. Discussing Metropolitan Reforms in Stockholm and Helsinki, VS Verlag für Sozialwissenschaften, Wiesbaden.

HALL P. and PAIN K. (2006), The Polycentric Metropolis. Learning from mega-city regions in Europe, Earthscan, London. 
HAMNETT C. (1996) "Why Sassen is Wrong : A Response to Burgess", Urban Studies, 33, 1, pp. 107-110.

HAMNETT C. (2003), Unequal City. London in the Global Arena, Routledge, London.

HANCKÉ B. (Ed.) (2009), Debating Varieties of Capitalism, A Reader, Oxford.

HÄUSSERMANN H. and HAILA A. (2004), “The European City : A Conceptual Framework and Normative Project", in KAZEPOV Y. (Ed.), Cities of Europe. Changing Contexts, Local Arrangements, and the Challenge to Urban Cohesion, Blackwell, Oxford, pp. 43-64.

HÄUSSERMANN H. and ROOST F. (2000), “Globalisierung, Global City”, in HÄUSSERMANN H. (Ed.) (2000), Großstadt. Soziologische Stichworte, Leske + Budrich, Opladen, pp. 79-91.

HOFMEISTER B. (1969), Stadtgeographie, Georg Westermann, Braunschweig.

HOFMEISTER B. (1980), Die Stadtstruktur. Ihre Ausprägung in den verschiedenen Kulturräumen der Erde, Wissenschaftliche Buchgesellschaft, Darmstadt.

HOHENBERG P. and LEES L.H. (1995), The Making of Urban Europe 1000-1994, Harvard University Press, Cambridge.

HOYLER M. (2011), “External relations of German cities through intra-firm networks - a global perspective", Raumforschung und Raumordnung, 69, pp. 147-159.

KAZEPOV Y. (2005), "Cities of Europe : Changing Contexts, Local Arrangements, and the Challenge to Social Cohesion", in KAZEPOV Y. (Ed.), Cities of Europe, Blackwell, Oxford, pp. 3-42.

KEIL R. and BRENNER N. (2003), "Globalisierung, Stadt und Politik“, in SCHARENBERG A. and SCHMIDTKE O. (Eds., 2003), Das Ende der Politik? Globalisierung und der Strukturwandel des Politischen , Verlag Westfälisches Dampfboot, Münster, pp. 254-276.

KLEINMAN M., MATZNETTER W. and STEPHENS M. (1999), European Integration and Housing Policy, Routledge, London and New York.

LÄPPLE D. (2000), “Globalisierung, Global City”, in HÄUSSERMANN H. (Ed.) (2000), Großstadt. Soziologische Stichworte, Leske + Budrich, Opladen, pp. 79-91.

LE GALÈS P. (2002), European Cities. Social Conflicts and Governance, Oxford University Press, Oxford.

LE GALÈS P. (2011), Le retour des villes européennes, Sociétés urbaines, mondialisation, gouvernement et gouvernance, 2e édition augmentée d'une préface inédite, Presses de la Fondation Nationale des Sciences Politiques, Paris.

LICHTENBERGER E. (1970), “The Nature of European Urbanism”, Geoforum, 1, 4, pp. 45-62.

LICHTENBERGER E. (1972), “Die europäische Stadt - Wesen, Modelle, Probleme”, Berichte für Raumforschung und Raumplanung, 16, 1, pp. 3-25.

MATZNETTER W. and MUNDT A. (2012), "Housing and Welfare Regimes", chapter 15, in CLAPHAM D. et al. (eds.), The SAGE Handbook of Housing Studies, SAGE, London.

MATZNETTER W. and MUSIL R. (Eds.) (2011), Europa : Metropolen im Wandel, Mandelbaum Verlag, Wien, pp. 274-294.

MUSIL R. (2009), "Global capital control and city hierarchies : an attempt to reposition Vienna in a world city network", Cities, 26, pp. 255-265.

OBERHUMMER E. (1915), “Amerikanische und europäische Städte”, Memorial Volume of the Transcontinental Excursion of 1912 of the American Geographical Society of New York, The American Geographical Society, New York, pp. 163-184. 
PASSARGE S. (Ed., 1930), Stadtlandschaften der Erde, Friederichsen, de Gruyter and Co. M.b.H., Hamburg.

PAIN K. (2012), “Spatial transformations of cities : global city-region ? Mega-city region ?”, in DERUDDER B., HOYLER, M., TAYLOR, P.J. and WITLOX, F. (Eds.) (2012), International Handbook of Globalization and World Cities, Edgar Elgar, Cheltenham, pp. 83-93.

PENNIX R., BERGER M. and KRAAL K. (Eds.) (2006), The dynamics of International Migratgion and Settlement in Europe. A State of the Art, AUP (IMISCOE Joint Studies series), Amsterdam.

PETRELLA R. (2000), “The Future of Regions : Why the Competitiveness Imperatives should not prevail over Solidarity, Sustainability and Democracy”, Geografiska Annaler, 82B, 2, pp. 67-72.

PHELPS A. N., PARSONS N., BALLAS D. and DOWLING A. (2006), Post-suburban Europe. Planning and Politics at the Margins of Europe's Capital Cities, Palgrave, Houndmills.

ROZENBLAT C. and CICILLE P. (2003), Les villes européennes. Analyse comparative, La Documentation Française, Paris.

SASSEN S. (1991), The Global City : New York, London, Tokyo, Princeton University Press, Princeton, NJ.

SASSEN S. (2006), Territory, Authority, Rights. From Medieval to global Assemblages, Princeton University Press, Princeton/Oxford.

SCHAMP E.W. (2011), "Europas jüngstes Finanzzentrum. Der Aufstieg Frankfurts zur europäischen Finanz-Metropole“, in MATZNETTER W. and MUSIL R. (Eds.) (2011), Europa : Metropolen im Wandel, Mandelbaum Verlag, Wien, pp. 53-66.

SCHÖLLER P. (1967), Die deutschen Städte, Franz Steiner Verlag, Wiesbaden.

SCHRÖDER F. (1999), Einzelhandelslandschaften in Zeiten der Internationalisierung, Birmingham, Mailand, München, LIS-Verlag, Passau.

SHORT J.A., KIM Y., KUUS M. and WELLS H. (1996), “The Dirty Little Secret of World Cities Research : Data Problems in Comparative Analysis”, International Journal of Urban and Regional Research, 20, pp. 697-717.

SIEBEL W. (Ed.) (2004), Die europäische Stadt, Suhrkamp, Frankfurt am Main.

SOJA E. (1985), "Regions in Context : Spatiality, Periodicity, and the Historical Geography of the Regional Question", Environment and Planning D, Society and Space, 3, pp. 175-190.

STORPER M. (1997), The Regional World. Territorial development in a global economy, Guilford Press, New York/London.

SZIRMAI V. (2011), Urban Sprawl in Europe, AULA Kiadó, Budapest.

TAYLOR P. (2004), "Is there a Europe of Cities ? World Cities and the Limitations of Geographical Scale Analysis", in SHEPPARD E. and MASTER R. B. (Eds.) (2004), Scale and Geographic Inquiry: Nature, Society, and Method, Blackwell, Oxford, pp. 213-235.

TAYLOR P., DERUDDER B., HOYLER M., PAIN K. and WITLOX F. (2011), "European Cities in Globalization”, in TAYLOR P., NI P., DERUDDER B., HOYLER M., HUANG J. and WITLOX F. (Eds.) (2001), Global Urban Analysis. A Survey of Cities in Globalization, Earthscan, London, pp. 114-136.

TAYLOR M. and DERUDDER B. (2004), "Porous Europe : European Cities in Global Urban Arenas", Tijdschrift voor Economische en Sociale Geografie, 95, 5, pp. 527-538.

TAYLOR M. and HOYLER M. (2000), “The spatial order of European cities under conditions of contemporary globalisation", Tijdschrift voor Economische en Sociale Geografie, 91, 2, pp. 176-189. 
VANDERMOTTEN C., VERMOESEN F., DE LANNOY W. and DE CORTE S. (1999), Villes d'Europe.

Cartographie comparative, Crédit Communal de Belgique, Bruxelles.

WEBER M. (1976), Wirtschaft und Gesellschaft, Mohr, Tübingen.

WU J. and RADBONE I. (2005) "Global integration and the intra-urban determinants of foreign direct investment in Shanghai”, Cities, 22, 4, pp. 275-286.

ZEHNER K. (2011), “Von der Hauptstadt des Empire zur Alpha Global City. Die Stadtentwicklung Londons im Zichen von Globalisierung und Stadtentwicklungspolitik", in MATZNETTER W. and MUSIL, R. (Eds.) (2011), Europa : Metropolen im Wandel, Mandelbaum Verlag, Wien, pp. 39-51.

\section{ABSTRACTS}

This conceptual paper identifies a gap between two meaningful fields of research in urban geography: the first, old-established and reinforced by the European integration process, asks for recent and future trends, primarily on intra-urban development of cities on the European scale. The second focuses on inter-urban relations on a global scale, inspired by global city theories established since early 1990s. As a consequence of this research gap, a research agenda has been formulated with the aim to deliver the missing links between these two fields. Therein, three methodological improvements are put forward: first, more research has to be done to prove the widely accepted thesis of an existing link between global integration and internal urban structure. Second, the role of specific national politics for the production of a global city has to be examined - such as the type of welfare-regime or the impact of historical political structures. Finally, global city research should seriously consider the territorial arrangements that impinge upon the development of global cities on a national and a European scale.

Cet article conceptuel identifie un écart entre deux grands domaines de recherche en géographie urbaine : le premier, établi de longue date et renforcé par le processus d'intégration européen, se concentre principalement sur les tendances récentes ou à venir en matière de développement intra-urbain à l'échelle européenne. Le second pose la question des relations inter-urbaines à l'échelle globale, née des théories sur la Ville Globale échafaudées depuis le début des années 1990. Au vu de cette lacune, un programme de recherche a été mis en place afin de fournir les chaînons manquants entre ces deux domaines. A cet égard, trois améliorations méthodologiques sont proposées : la première est la nécessité d'accroître le volume des recherches pour prouver la thèse largement admise d'un lien entre intégration globale et structure urbaine interne. En second lieu, il convient d'analyser le rôle des politiques nationales spécifiques visant à produire une ville globale - tel que le type de système de sécurité sociale ou l'impact des structures historico-politiques. Enfin, la recherche sur la Ville Globale devrait considérer de façon approfondie les dispositions territoriales qui empiètent sur le développement des villes globales tant à l'échelle nationale qu'à l'échelle européenne.

\section{INDEX}

Mots-clés: ville européenne, ville globale, régions métropolitaines globales, déterritorialisation Keywords: European City, Global City, Global City Regions, de-territorialisation 


\section{AUTHORS}

\section{WALTER MATZNETTER}

Institut für Geographie und Regionalforschung, Universität Wien,

walter.matznetter@univie.ac.at

\section{ROBERT MUSIL}

Institut für Stadt- und Regional Forschung, Österreichische Akademie der Wissenschaften, Robert.Musil@oeaw.ac.at 